\author{
Naila SAMADOVA, \\ orcid.org/0000-0001-5231-1263 \\ Doctor of Philological Sciences, \\ Scientific Worker \\ Institute of Manuscripts named after Mahammad Fuzuli \\ (Baku, Azerbaijan)nailesamadova@yahoo.com
}

\title{
AZERBAIJANI POET NIZAMI GANJAVI IN SOURCES OF MANUSCRIPT
}

The literary heritage of the great Azerbaijani poet Nizami Ganjavi has been in the spotlight for centuries. From the 40s of the XX century to the present day, Azerbaijani scholars who study of Nizami conducted valuable research on the poet's work. Mammad Said Ordubadi, a prominent representative of XX century Azerbaijani literature, is also the author of a series of articles about our great poet. Autographed copies of these articles are kept in the personal archive of the writer at the Institute of Manuscripts named after Mahammad Fuzuli of ANAS.

Nizami Ganjavi's period, environment, life and work are studied on the basis of reliable sources in the articles entitled as "Nizami's period and life", "The environment in which Nizami was born and lived", "Poets who imitated Nizami", "Nizami revolutionary poet", "About Nizami's works", "Sheikh Nizami Ganjali", "Religion in Nizami".

Mammad Said Ordubadi connects the fact that an Azerbaijani poet does not write in his native language with his frequent emigration and for this reason he came to the conclusion that his works were not available, that many of his works were lost, and that "Khamsa" was a drop in the ocean of Nizami's poetry. The five works included in "Khamsa" have survived to the present day because they are protected in the state treasury.

Mammad Said Ordubadi's article "Azerbaijani literature in the XII century and its influence on the Eastern classical literature" systematically examines the Azerbaijani literature of the XII century, mainly the works of Nizami Ganjavi and its influence on the Eastern classical literature. Although the complex historical events of that period, religious quarrels, and the chaos caused by the fall of the Seljuk dynasty changed the political life of Azerbaijan, they did not affect the literary environment. Oriental poets wrote commentaries on Nizami Ganjavi's works and imitated him.

Mammad Said Ordubadi's articles dedicated to the great master of Azerbaijani literature of the XII century Nizami Ganjavi are important in terms of a more comprehensive study of the peculiarities of Nizami's art, Nizami's attitude to poets who lived before him, and the interpretation of historical events. Nizami Ganjavi's period, life and creativity are studied and analyzed in these works, which tell about the great poet who was always at the top of Near and Middle Eastern poetry with his beautiful and unique works. The articles about Nizami Ganjavi of prominent researcher and scholar Mammad Said Ordubadi who studied of Nizami are valuable examples of studying of Nizami.

Key words: Nizami, Ordubadi, article, poet, manuscript, archive.

Наиля САМАДОВА, orcid.org/0000-0001-5231-1263 доктор філологічних наук, науковий працівник

Інституту рукописів імені Мухаммеда Фізулі (Баку, Азербайджан) nailesamadova@yahoo.com

\section{АЗЕРБАЙДЖАНСЬКИЙ ПОЕТ НІЗАМІ ГЯНДЖЕВІ У ДЖЕРЕЛАХ РУКОПИСУ}

Літературний спадок великого азербайджанського поета Нізамі Гянджеві століттями перебуває у иентрі уваги. Із 40-х років XX століття до наших днів азербайджанські науковці, які досліджували спадок Нізамі, проводили иінні дослідження творчості поета. Мамед Саїд Ордубаді, провідний представник азербайджанської літератури XX століття, який є також автором серії статей про нашого великого поета. Копії цих статей $з$ автографами зберігаються в особистому архіві письменника в Інституті рукописів ім. Мухаммеда Фізулі НАНА.

Період, оточення, життя і творчість Нізамі Гянджеві вивчають на основі достовірних джерел у статтях «Період і життя Нізамі», "Середовище, в якому народився і жив Нізамі», "Поети, які копіюють Нізамі», «Нізамі - револючійний поет», «Про творчість Нізамі», «Шейх Нізамі Гянджеві», «Релігія у Нізамі».

Мамед Саїд Ордубаді припускає, щзо азербайджанський поет не пише рідною мовою через часткову імміграцію, він дійшов висновку, щз через це його твори недосяжні, багато з них були втрачені, отже, «Хамса» - лише крапля в море поезї Нізамі. П'ять творів, які увійшли у «Хамсу», збережені до наших днів, тому перебувають на зберіганні в державній скарбнищі.

У статті Мамеда Саїда Ордубаді «Азербайджанська література ХІІ століття та ї̈ вплив на східну класичну літературу» систематично опрацьовується азербайджанська література ХІІ століття, в основному 
представлена творами Нізамі Гянджеві, та ї̈ вплив на східну класичну літературу. Хоча складні історичні подіі того періоду, релігійний розбрат і хаос, спричинений падінням династї Сельджуків, змінили політичне життя Азербайджану, але вони не торкнулися літературного середовища. Східні поети писали коментарі до творів Нізамі Гянджеві і наслідували його.

Статті Мамеда Саїда Ордубаді, присвячені великому майстру азербайджанської літератури ХІІ століття Нізамі Гянджеві, важливі з точки зору всебічного вивчення особливостей мистецтва Нізамі, його відномення до поетів, які жили до нього, та інтерпретації історичних подій. Період, життя і творчість Нізамі Гянджеві вивчають і аналізують у цих статтях, які розповідають про великого поета, який завжди був на вершині поезіі Ближнього та Середнього Сходу своїми прекрасними та унікальними творами. Цінним прикладом вивчення доробку поета є статті про Нізамі Гянджеві відомого дослідника Мамеда Саїда Ордубаді.

Ключові слова: Низами, Ордубаді, стаття, поет, рукопис, архів.

Introduction. The legacy of the 12th century Azerbaijani poet Nizami Ganjavi has been a source of research for memoirs authors, scholars and poets for nearly nine centuries. Mammad Said Ordubadi is also one of the personalities inspired by Nizami's genius. A series of articles about Nizami Ganjavi are preserved in the personal archive of Mammad Said Ordubadi, who is a prominent representative of XX century Azerbaijani literature, prose writer, poet, playwright, publicist, translator, kept at the Institute of Manuscripts named after Mahammad Fuzuli of ANAS. Ordubadi, the founder of the historical novel genre in Azerbaijani literature, is the author of the novel "Sword and Quill", which revives the period, life and literary activity of the great poet Nizami Ganjavi.

In connection with the novel "Sword and Quill" Mammad Said Ordubadi reviewed and studied numerous sources, wrote articles about the period, environment, life and work of Nizami Ganjavi, as well as his contemporaries. Autographed copies of the articles are kept in the author's personal archive at the Institute of Manuscripts. The large article entitled "Nizami's period and life" consists of several copies. The perfect copy consists of 109 pages, is an autograph written in the Arabic alphabet (Ordubadi, s.u.415a). The other three copies consist of 6,10 , 12 pages (Ordubadi, s.u.416) and the substantive corrections made to these copies give reason to believe that they are the original version of the work.

The archive also contains the author's articles consists of 72 pages about Nizami Ganjavi (Ordubadi, s.u.417). These are given under the headings "The environment in which Nizami was born and lived", "Poets who imitated Nizami", "Nizami - a revolutionary poet", "About Nizami's works", "Sheikh Nizami Ganjali".

Discussion. In the personal archive of Mammad Said Ordubadi there are 40-page retail copies of the large-scale works about the great poet "Literature in Nizami's time", "East on the eve of Nizami's birth", "Nizami's birthplace and environment". It is clear from these parts that the writer thoroughly worked on a large-scale research work dedicated to Nizami
Ganjavi, wrote separate parts in several variants, and finally created a perfect version of his work about the great poet.

The author also corrected the manuscript of the perfect copy of Ordubadi's article "Nizami's period and life". Some words and sentences have been abbreviated. Some have been abbreviated and replaced with other words and sentences. This largescale work, consisting of sections entitled "Arab invasion in Azerbaijan", "Religion and sectarian conflict in Azerbaijan", "People's uprising against Islam", "Literature in the Nizami period" traces the history of Azerbaijan before the poet's life. The author gives detailed information about the political and economic situation of Azerbaijan since the VII century and states that in all the works of Nizami Ganjavi he was not indifferent to the difficult situation in Azerbaijan and was influenced by historical events. Speaking in this context, Ordubadi researched the period and life of the poet and first of all tried to determine what historical events he was influenced by.

Summarizing the historical events, the author notes that Nizami Ganjavi was born during the reign of Sultan Sanjar, at a time when Azerbaijan was groaning in blood, childhood and youth coincided with a difficult period, and emphasizes that the period of Nizami's poetry began with the extinction of the Seljuk dynasty. The history of writing Nizami Ganjavi's works dates back to the reign of the Atabegs, who belonged to the Eldiguzids dynasty. The article describes in detail the historical events of the Atabeg period, the political and economic situation of the country in this period, the miserable and difficult situation of the people, and Ordubadi, as a historian scholar, expressed his attitude to these events.

During such a difficult period for the nation and the country, Nizami Ganjavi created his rich works. However, historical events of the time are not reflected in his works. However, his life and work went through bloody, terrible events, and the poet with his works showed that he is always high in terms of political thought and political judgment. Comparing Nizami and Firdovsi in this regard, Ordubadi notes that "today, although we can read the histori- 
cal events of the time in Firdovsi's work, we still do not come across the poet's personal judgments about these events. Although there is a high level of art and high imagery, we do not see a comprehensive analysis of the causes of historical events" (Ordubadi, s.u.415b: 39).

Although Nizami's work "The Book of Alexander" does not cover the historical events of the time, it is not only a work of art, but also a valuable document on the political judgments of the great poet. However, “... Nizami's aim in using a historical event and historical figure was not to compose a poem as it is historical and convey it to the reader. Therefore, when the time comes, the historical events and historical figures he describes in his poems take on different shades of meaning by Nizami” (Karimli, 2002: 145).

Ordubadi touches on the issue of legend in the works of both poets, shows that Nizami's works do not contain much fantasy compared to Firdovsi, and says that even if this is the case, it is given critically and the poet does not try to convince his readers. For instance, although the poet writes that Alexander went into darkness and sought the water of life, at the same time he says, "Alexander will find the source of life only with this work of mine".

Mammad Said Ordubadi compares Firdovsi's environment with Nizami's. Firdovsi, who lived during the Ghaznavids period, had ample opportunities to create his historical works. It was not difficult to create an important work in a peaceful and quiet environment. But in the difficult and complicated conditions in which Nizami lived, it took great perseverance and self-sacrifice to create a work of art that dealt with social issues. "One of the most important differences between Nizami and Firdovsi is undoubtedly the issue of ideas and worldviews. Firdovsi and Nizami lived in different times, in different views and meetings, everyone tried to respond to the search for ideas and opinions of their time" (Yusifli, 2011: 2XII). Mammad Said Ordubadi also analyzes the war scenes described in the works of Nizami and Firdovsi, comparing the attitudes of both poets to these wars.

Human upbringing is one of the important aspects of Nizami Ganjavi's philosophy of life. In all the works of the great poet, Ordubadi substantiates his rejection of innate nobility and innate upbringing, his claim that a new man can only be scientific and educated with age and science, and completely rejects Firdovsi's philosophies in this area.

While Firdovsi wrote "it is better if both the woman and the dragon are buried in the ground, the world is purer than both impure", Nizami Ganjavi created an exemplary image of femininity in the example of Nushaba and revived women's activities not only as women but also in economic and political spheres. At the same time, "the poet's poetic coverage of a wide artistic context, his connection with world culture, his use of Turkish, Arabic words and sayings and parables of other peoples are the features that are not noticeable in Firdovsi's art" (Arasli, 2004: 64).

Mammad Said Ordubadi attributes the 20-year pause between the genius poet's "Treasure of Mysteries" and "Khosrov and Shirin" and the fact that an Azerbaijani poet did not write in his native language to his frequent emigration and for this reason, he estimates that his works were not available, that many of his works were lost, and that "Khamsa" is a drop in the ocean of Nizami's poetry. The five works included in "Khamsa" have survived to the present day because they are protected in the state treasury.

In his work "Nizami's period and life" Ordubadi filters not only the works of Nizami Ganjavi, but also the ways of development of literature at that time analyzing the value that Shirvan shahs show to poets and the importance they attached to the art of poetry, he concludes that their policy did not allow poets to create works in the national language. Showing that the literature of the Nizami period was concentrated in the palaces of four great governments: Shirvanshahs, Ghaznavids, Seljuks and Atabeys, Kharezmshahs, Ordubadi gives information about the poets working in these palaces, examines their lives and activities on the basis of examples from Abulula Ganjavi, Khagani Shirvani, Felaki Shirvani. The writer compares Nizami Ganjavi with other writers of his time and emphasizes that the great poet had a great reputation in the field of poetry not only in the palace of Shirvanshahs, but also in the palace of Seljuks, Kharezmshahs, Ghaznavids. At that time, Khagani and Felaki, along with many other poets, took part in the conference of poets organized by Abulula Ganjavi. However, Nizami Ganjavi did not belong to this society and developed his creativity independently. Although he was not one of the palace poets, he sent his works to the shahs, including Shirvanshah Akhsitan, due to financial need" (Ashurbeyli, 2006: 200). The great poet led the Akhis persuasion in Ganja and Shirvan. He "... accepted the most courageous of all Sufi sects and currents, the sect that more courageously defended the workers of the city" (Bertels, 2017: 33). The allies gathered around him thought of the brotherhood of the people, the unity of the people in order to prevent bloody wars.

While the majority of Ganja intellectuals moved to the palace of Shirvan shahs, Tabriz, Hamadan, the great poet endured hunger and deprivation and did not leave his native city and people. Nizami Ganjavi was "a poet who grew up among the broad masses 
of the people, and when expressing his courageous and justified critical views, he relied first of all on the people themselves. $<\ldots>$ The open-minded, forwardthinking leader of his time managed to burn into the condition of all working people" (Agayev, 1964: 85).

In the opera libretto he wrote in the following years words of great Nizami "The robe made by the kings is placed only on the shoulders of those who bow down to them... However, I will not allow a head carrying the deeds and aspirations of the Azerbaijani people to bow before every despicable person" (Ordubadi, s.u.238: 18) by these words Ordubadi shows that he was attached to the people and that a piece of barley bread was more important than the blessings of the palace.

Nizami Ganjavi, who took the subject of his works from the environment in which he lived, from the life of the people, never competed with other poets, he was only at the top with his art. Because in addition to being a great poet, he was a scientist and thinker who was well versed in various fields of science and had extensive knowledge about the life of other nations. $\mathrm{He}$ "he researched different sources when he thought about each new subject and, as he said, took their essence" (Safarli, Yusifli, 2008: 137).

Mammad Said Ordubadi's article "Azerbaijani literature in the XII century and its impact on Eastern classical literature" can be considered as a kind of continuation of "Nizami's period and life". In this example, the Azerbaijani literature of the XII century, mainly the works of Nizami Ganjavi and its influence on the Eastern classical literature are systematically studied. Although the complex historical events of that period, religious quarrels, and the chaos caused by the fall of the Seljuk dynasty changed the political life of Azerbaijan, they did not affect the literary environment. Oriental poets wrote commentaries on Nizami Ganjavi's works and imitated him. The lordscalso demanded that the palace poets write "Khamsa" in reference to Nizami's "Khamsa". The poets of Isfahan Nami and Kerman wrote "Farhad and Shirin" in reference to "Khosrov and Shirin", Shiraz Poet Maktabi, Jigatay poet Hilali and Amir Nizameddin Suheyli wrote "Leyla and Majnun" and Abdurrahman Jami wrote "Haft Awrang" based on "The Seven Beauties". The famous Indian poet Amir Khosrov Dahlavi wrote "Khamsa" in view of the four books of "Khamsa" by Hatifi Khorasani. According to the sources, "87 imitative poems for the "Treasure of Mysteries", 92 for the "Khosrov and Shirin", 145 imitative poems for the "Layla and Majnun", 42 imitative poems for the poem "The Seven Beauties" and 23 for the historical poem "The Book of Alexander" were written" (Habibbayli, Ibrahimov, 2018: 274).
This article provides information about the poets who referenced "Khamsa", shows how successful they are, some are praised, some are criticized, and even those who succeed are told that they have not been able to conquer the Nizami summit. However, according to Ordubadi's opinion, “... personal creativity and originality could not show itself in reference, and the poet was forced to catch a quote disease" (Ordubadi, s.u.420: 8).

Both Nizami Ganjavi's contemporaries and poets of later times benefited from it. For example, his contemporary, the Samarkand poet Ashrafi, received advice from the great Nizami about his works.

In the period of Nizami Ganjavi "Islamic society was rocked by sectarian strife, such as Alawite and Sunni Ism, on the one hand, and debates such as Sufism and Sharia law, on the other. Nizami was a devout and loyal Muslim who believes in God and is attached to the Prophet" (Rasulzada, 2011: 65).

In Nizami Ganjavi's works, Mammad Said Ordubadi tried to give the poet's attitude to religion more comprehensively in his article "Religion in Nizami". The author's personal archive contains an autographed copy of the article written in the Arabic alphabet. In the article, Ordubadi compares Nizami's works with those of Rudaki and his contemporaries and concludes that while Rudaki and his contemporaries begin the prefaces of their works with the theme of love, Nizami begins the prefaces of his works with the name of God. Ordubadi substantiated his conclusions with examples from Rudaki's work and Nizami Ganjavi's "Khamsa".

Commenting on the genius poet's attitude to religious beliefs, academician Mammad Jafar Jafarov said that "many researchers have called the traditional introductions in Nizami's works, such as monotheism, minajat, and the definition of the prophet, "the official part" and have not given them the attention they deserve. If we pay attention, we will see that even in these official passages there is a lot of material to understand the poet correctly" (Mammad Jafar, 1982: 63). Mammad Said Ordubadi also paid attention to these passages and commented on the great poet's attitude to religion in the works of Nizami Ganjavi.

In the introduction to his works in addition to what he wrote about God, creation, the prophet, and his destiny, the poet, who saw all the horrors of the "...injustice of his time, the injustice done to the poor and the needy, prayed to God: sprinkle water on the flames of injustice, place the wind below the earth - figuratively advises to destroy the universe, which is based on oppression and heresy" (Azadə, 1979: 93). 
In Nizami Ganjavi's work, religion and the great poet's attitude to religion can be summarized in the writer's own words, based on Mammad Said Ordubadi's article "Religion in Nizami": "Nizami is a very strong believer compared to all the poets who grew up in the East. $<\ldots>$ The school of religion in Nizami's works is only a school of Nizami's own and created by him. $<\ldots>$ This school starts only from Nizami. After Nizami, all the works, even romance novels, stories, and mourning books in general, are under the influence of this school" (Ordubadi, s.u. 414: 1, 2).

Mammad Said Ordubadi's personal archive includes a large-scale work on Nizami Ganjavi, as well as a small series of articles, as mentioned earlier. The one-page article in the archive entitled 'The environment in which the great poet lived" is an autographed copy written in the Arabic alphabet, with corrections. "The environment in which Nizami was born and lived" (Ordubadi, s.u. 389) is relatively extensive and consists of six pages. In this article, the author mainly talks about the historical events of the period, the history of writing the works of the great poet. "The article "Poets who imitated Nizami" discusses Sadi "Bustan" and Nizami, Alisher Navai and Nizami's "Khamsa". In the article "Nizami revolutionary poet", the author shows that the great poet is close to the people and lives freely without going to palaces like other poets, according to Ordubadi, the closeness to the people, the revolutionary spirit are more clearly reflected in "Khosrov and Shirin" with its given examples. The article "On the works of Nizami" analyzes the works of the great poet and evaluates him as a master of fluent speech. The article "Sheikh Nizami Ganjali" refers to the commentaries on the life and works of the poet, gives brief information about the views of powerful poets, as well as on the basis of Ordubadi's own research, the poet's views on Turkism.

Mammad Said Ordubadi masterfully revived the artistic image of the great poet in the novel "Sword and Quill". Undoubtedly, the importance of his research on Nizami Ganjavi in the creation of this great historical novel is undeniable. Autographed copies of the novel are preserved in the author's personal archive. It should be noted that the archive also contains an opera libretto written by Ordubadi about the great poet and a screenplay libretto for the feature film Nizami (Ordubadi, s.u.235).

Conclusion. Mammad Said Ordubadi's articles dedicated to the great master of Azerbaijani literature of the XII century Nizami Ganjavi are important in terms of studying the features of Nizami's art, Nizami's attitude to the poets who lived before him, the historical events of the time, the life and work of Omar Khayyam, Mahsati Ganjavi, Khagani Shirvani, as well as other poets of the East. With these beautiful and unique works, Ordubadi proved to be a perfect connoisseur not only of Nizami's time and creativity, but also of Eastern literature, with these examples, which are valuable works in the study of the life and environment of the great poet, who was always at the top of Near and Middle Eastern poetry. In a series of articles about Nizami Ganjavi, the scientist analyzes and studies his period, life and work based on reliable sources, and expresses his own scientific considerations. Prominent researcher and scholar Mammad Said Ordubadi's research on Nizami Ganjavi should be considered as a great success and valuable example in studying Nizami.

\section{BIBLIOGRAPHY}

1. Ordubadi M.S. Nizami's period and life. ANAS IM, f.14, s.u.415.

2. Ordubadi M.S. Nizami's period and life. ANAS IM, f.14, s.u.416.

3. Ordubadi M.S. Articles about Nizami. ANAS IM, f.14, s.u.417.

4. Karimli T. Nizami and history. Baku : Elm, 2002.

5. Yusifli Kh. Nizami Ganjavi: Predecessors and successors. Baku : Adiloglu, 2011.

6. Arasli N. Nizami's poetics (literary sources and means of artistic description). Baku : Elm, 2004.

7. Ashurbeyli S. Shirvanshahlar state. Baku. 2006.

8. Bertels Y. The great Azerbaijani poet Nizami. Baku : Elm, 2017.

9. Agayev A. Nizami and world literature. Baku : Azerbaijan State Publishing House, 1964.

10. Ordubadi M.S. Nizami. ANAS IM, f.14, s.u.238.

11. Safarli A., Yusifli Kh. History of Azerbaijani literature. Baku : Ozan, 2008.

12. Habibbayli I., Ibrahimov S. Middle-age century the unified Eastern literary process. I volume. "Laman Publishing Polygraphy" MMC, Baku. 2018.

13. Ordubadi M.S. Azerbaijani literature in the XII century and its influence on Eastern classical literature. ANAS IM, f.14, s.u. 420

14. Rasulzada M.A. Azerbaijani poet Nizami. Baku : "Teknur” publishing, 2011.

15. Mammad Jafar. Nizami's world of ideas. Baku : Yazhici, 1982.

16. Azada R. Nizami Ganjavi (life and art). Baku : Elm, 1979.

17. Ordubadi M.S. Religion in Nizami. ANAS IM, f.14, s.u.414.

18. Ordubadi M.S. The environment in which the great poet lived. ANAS IM, f.14, s.u. 389.

19. Ordubadi M.S. Nizami. ANAS IM, f.14, s.u.235. 


\section{REFERENCES}

1. Ordubadi M.S. Nizami's period and life. ANAS IM, f.14, s.u.415.

2. Ordubadi M.S. Nizami's period and life. ANAS IM, f.14, s.u.416

3. Ordubadi M.S. Articles about Nizami. ANAS IM, f.14, s.u.417.

4. Karimli T. Nizami and history. Baku: Elm, 2002.

5. Yusifli Kh. Nizami Ganjavi: Predecessors and successors. Baku: Adiloglu, 2011.

6. Arasli N. Nizami's poetics (literary sources and means of artistic description). Baku: Elm, 2004.

7. Ashurbeyli S. Shirvanshahlar state. Baku. 2006.

8. Bertels Y. The great Azerbaijani poet Nizami. Baku: Elm, 2017.

9. Agayev A. Nizami and world literature. Baku: Azerbaijan State Publishing House, 1964.

10. Ordubadi M.S. Nizami. ANAS IM, f.14, s.u.238.

11. Safarli A., Yusifli Kh. History of Azerbaijani literature. Baku: Ozan, 2008.

12. Habibbayli I., Ibrahimov S. Middle-age century the unified Eastern literary process. I volume. "Laman Publishing Polygraphy" MMC, Baku. 2018.

13. Ordubadi M.S. Azerbaijani literature in the XII century and its influence on Eastern classical literature. ANAS IM, f.14, s.u. 420 .

14. Rasulzada M.A. Azerbaijani poet Nizami. Baku: “Teknur” publishing, 2011.

15. Mammad Jafar. Nizami’s world of ideas. Baku: Yazhici, 1982.

16. Azada R. Nizami Ganjavi (life and art). Baku: Elm, 1979.

17. Ordubadi M.S. Religion in Nizami. ANAS IM, f.14, s.u.414.

18. Ordubadi M.S. The environment in which the great poet lived. ANAS IM, f.14, s.u. 389.

19. Ordubadi M.S. Nizami. ANAS IM, f.14, s.u.235. 